\title{
ASSESSING COMPLIANCE WITH SMOKE FREE LAWS IN BATU BURUK, TERENGGANU: A DIRECT OBSERVATION
}

\author{
Nik Nor Ronaidi bin Nik Mahdi ${ }^{1}$, Aniza binti Abd Aziz ${ }^{1}$, Rahmah binti Mohd. Amin ${ }^{1}$ and Yuzana binti \\ Mohd Yusop ${ }^{1}$
}

${ }^{1}$ Faculty of Medicine, Universiti Sultan Zainal Abidin (UniSZA), Medical Campus, Jalan Sultan Mahmud, 20400 Kuala Terengganu, Terengganu Darul Iman, Malaysia.

Corresponding author: Nik Nor Ronaidi bin Nik Mahdi

Email: ronaidimahdi@unisza.edu.my

\begin{abstract}
Batu Buruk beach has been gazetted as a non-smoking zone by Minister of Health under the initiative by Terengganu state government via their program known as 'Terengganu Bebas Asap Rokok' (TBAR). The smoking bans at Batu Buruk was enforced in order to preserve and protect the public from the dangers of cigarette smoke as well as to keep the city's environment clean and healthy. The objectives of this study were to assess the status of compliance to smoke free legislations and identify the potential aspects of violations in Batu Buruk, Terengganu, a gazetted smoke free area. A cross-sectional study using direct observation was conducted includes all indoor and outdoor public areas in Batu Buruk Beach. Data were collected using a standard checklist which was constructed based on the provisions of the law governing exposure to tobacco smoke as stated in Control for Tobacco Products Regulation (CTPR) 2004. The study revealed that the average for overall compliance on smoke-free policy was low (66.2\%). The average compliance for indoor (67.4\%) was higher as compared with outdoor (58.9\%). Thirteen smokers were discovered smoking outdoor in the area during the study. None of the owners provide smoking aid at their premises. Although the beach has been gazetted as a non-smoking zone for more than two years, it is disappointing that overall compliance was still minimal and smoking activities are still happening in the area. Along with intense health promotion activities, continuous enforcement, close monitoring and periodic evaluation would improve and ensure the successfulness of the programme.
\end{abstract}

Keywords: Smoke free, compliance, TBAR, Batu Buruk beach

\section{INTRODUCTION}

The tobacco control in Malaysia is regulated under the Control for Tobacco Products Regulation (CTPR) 2004, which is a component under Food Act 1983. The regulation was based on the guidance from the Framework Convention on Tobacco Control (FCTC), which includes six key strategies on tobacco control known as MPOWER by World Health Organization (WHO) in 2008. One of the effective strategies promoted in MPOWER is to protect people from exposure to second-hand tobacco smoke by total ban on smoking in public places ${ }^{1}$.

Smoke-free policies have been a significant action to curb tobacco use. Establishing smoke free zones is an efficient intervention because it is simpler to discourage individual from smoking than to encourage individuals to stop smoking. These smoke-free regions not only benefits in educating community about the risks of secondhand smoke exposure, but also help to denormalize smoking by making it socially unacceptable and unpleasant ${ }^{2}$. Compared to 20 years ago, the availability of smoke free area has increased markedly. Today an approximately 11 percent of the world's population lives in nations with legislation that require these areas to be smoke-free. Apart from restricting tobacco use, smoke-free policies are unique in terms of protecting non-smokers from the effect of second-hand smoke $(\mathrm{SHS})^{3}$.

Therefore, section 11 of CTPR 2004 provides public protection from exposure to tobacco smoke as stated in FCTC Article 8 where several public places such as hospital, public transport, and eating places were gazetted as smoke free area. Moreover, section 22 of CTPR 2004 empowers Minister of Health to declare any specific places as non-smoking area, which serves as an extension or addition to the gazetted smoke free area under section 11 of CTPR 2004.

In conjunction with this law, an initiative called 'Terengganu Bebas Asap Rokok' (TBAR) was initiated by the Terengganu state government which was launched on $14^{\text {th }}$ February 2014. Batu Buruk became the first place chosen as a pioneer project for this initiative in Terengganu. As a result, all indoor and outdoor public places in an area of approximately 48.85 acres surrounding Batu Buruk Recreational Beach was gazetted by the Minister of Health as a smoke free area 
starting on $1^{\text {st }}$ of July 2017 , pursuant to the authority granted by section 22 of CTPR $2004^{4-6}$.

After two years of numerous health education and law enforcement activities carried out by all stakeholders in this newly gazetted smoke free area $^{6}$, it is therefore appropriate to evaluate and assess the compliance to this initiative and smoke free legislations. Compliance was defined as the degree to which a law or other legislative instruments is being obeyed ${ }^{7}$. This study measured the level of compliance to smoke free legislations and also identified the types and potential aspects of violations.

\section{METHODS}

\section{Study Design and Location}

A cross-sectional study involving direct observation was conducted on Wednesday, $26^{\text {th }}$ June 2019 to assess the compliance towards smoke free policy in the gazetted area under Terengganu Bebas Asap Rokok (TBAR) initiative in Batu Buruk Beach. It is located in the district of Kuala Terengganu. It was the pilot project under TBAR initiative. This area was announced as smoke free on July 1st, 2017 under Section 22 of Control of Tobacco Product Regulation 2004.

\section{Data collection}

The direct observation procedure includes all indoor and outdoor public spaces throughout the gazetted area. Indoor public spaces consist of eating places, mosque, sport complex, and aquatic centre. Outdoor public spaces and the whole study area were divided into 7 zones as follows:

1. Al-Mukhtafi Mosque Billah Shah

2. Sports complex (Hockey stadium)

3. Terengganu Aquatic Centre

4. Batu Buruk beach

5. Dataran Pantai Batu Buruk

6. Batu Buruk Recreational Park 1

7. Batu Buruk Recreational Park 2

A total of 14 trained data collectors involved in this study. All data collectors were trained on smoke-free law and its provisions, along with filling of standard checklist used for the study. They were divided into seven teams consisted of two data collectors each. Each team was assigned into one out of the seven zones mentioned above for observation of all indoor and outdoor premises.

Informed consent was obtained from the owner before premise observation. The owner was initially informed that researchers are not the law enforcement officer and no photo will be taken. As the owner agreed to participate in the study, the observations were conducted based on the standard checklist criteria to determine the compliance status of each premise. The direct observation procedure for each premise took approximately 30 minutes to complete.
In cases where the owner was not available, researcher requested the workers to call and sought permission from the owners. If the owners agreed, the observation was continued and in cases where the owners declined to allow for premise observation, the premise was excluded and researchers moved to the next premise.

\section{Research Tool}

The observational checking methods were adapted from Johanna et. al $(2014)^{7}$. The original criteria checklist was constructed based on the provisions of the law governing exposure to tobacco smoke as stated in Control for Tobacco Products Regulation (CTPR) 2004. The compliances with the regulations are evaluated in two aspects namely public compliance and premises owners' compliance. Public compliance is measured by the presence of smoking activity or evidence of smoking activity such as cigarette butts and cigarette smoke odour. Premises owners' compliance were measured by the provisions mandating actions that reinforce or support a smoke-free environment, such as a prohibition on ashtrays, ashbins or lighter, and the presence of signage with specific dimensions, and appropriate format and content as required by $\operatorname{law}^{7}$.

The assessment criterions are listed below and were applied for both indoor and outdoor premise observations:

1. Absence of smoking activities at the time of observation (smoking and vape)

2. Absence of cigarette butts

3. Absence of smoke odor

4. Absence of smoking aids example ashtrays, ashbins and lighter

5. Presence of "NO SMOKING" signage

a) Appropriate size of signage $(40 \times 50 \mathrm{~cm}$ minimum size)

b) Appropriate content (standard information)

\section{Statistical Analysis}

The data was analyzed using SPSS version 22.0 software. Descriptive statistical analysis was applied such as frequency and percentage (\%) for categorical data. The average compliance was calculated as the average of all the percentages based on indoor, outdoor and overall observations.

\section{Ethical Consideration}

Detail description for the research conduct, its confidentiality and voluntary participation was explained to all premise owners. A written and verbal consent was also taken from the premise owners. The information provided was kept private and confidential, without requiring them to reveal their identities and will not be exposed to the health authority. Ethical approval from UniSZA Human Research Ethical Committee (UHREC) was obtained before data collection (UniSZA/UHREC/2019/110). 


\section{RESULTS}

A total of 51 premises which consisted of 44 indoor premises and 7 outdoor premises were observed during the study. Table 1 shows premises owners' compliance towards smoke free policy. Among 51 premises in Terengganu Bebas Asap Rokok (TBAR) area, the average for overall compliance om smoke-free policy was $66.2 \%$. The average compliance for indoor and outdoor were $67.4 \%$ and $58.9 \%$ respectively. Detail observations according to criterion revealed 41 indoor premises $(93.2 \%)$ and four outdoor premises $(57.1 \%)$ have no smoking activities found at the time of observation. No lighter was found in 42 indoor premises (95.5\%) and seven outdoor premises (100.0\%). There was no ashtray or ashbin found during observation in both indoor and outdoor premises. Twenty-five indoor $(56.8 \%)$ and three outdoor $(42.9 \%)$ premises were found to have cigarette butts. All of the cigarette butts were found on the floor.

'NO SMOKING' signage was noticed in 20 indoor premises (45.5\%). Out of these, 16 premises have appropriate size and 13 premises have appropriate content of standard information. Meanwhile, observation at outdoor premises showed 'NO SMOKING' signage with proper size and content of standard information were found only in two premises (28.6\%). Among all premises, two indoor premises $(4.5 \%)$ and two outdoor premises $(28.8 \%)$ were found to have smoke odour during observation.

Table 2 shows the number of smokers during observation. A total of thirteen smokers were identified mainly at outdoor (9 smokers).

Table 1. Findings of premises owners' compliance using observational criteria $(n=51)$

\title{
Observational criteria
}

Frequency (\%)

\begin{tabular}{llll} 
& $\begin{array}{l}\text { Indoor } \\
(\mathbf{n}=44)\end{array}$ & $\begin{array}{l}\text { Outdoor } \\
(\mathrm{n}=7)\end{array}$ & $\begin{array}{l}\text { Overall } \\
(\mathrm{n}=51)\end{array}$ \\
\hline $\begin{array}{l}\text { 1. Absence of smoking activities at the time of observation } \\
\text { (smoking and vape) }\end{array}$ & $41(93.2)$ & $4(57.1)$ & $45(88.2)$ \\
$\begin{array}{l}\text { 2. Absence of cigarette butts } \\
\text { 3. Absence of smoke odour }\end{array}$ & $19(43.2)$ & $4(57.1)$ & $23(45.1)$ \\
$\begin{array}{l}\text { 2.a) Absence of ashtrays or ashbins } \\
\text { 2.b) Absence of lighter }\end{array}$ & $42(95.5)$ & $5(71.4)$ & $47(92.1)$ \\
3.a) Presence of 'NO SMOKING' signage & $42(95.5)$ & $7(100.0)$ & $49(96.1)$ \\
3.b) appropriate size of signage - 40X50cm minimum size & $16(36.4)$ & $2(28.6)$ & $18(35.3)$ \\
3.c) appropriate content of standard information & $13(29.5)$ & $2(28.6)$ & $15(29.4)$
\end{tabular}

Average compliance (\%)

67.4

58.9

66.2

Table 2. Description of smokers during observation $(n=13)$

\section{Premises}

\author{
n (\%)
}

Indoor

$4(30.8)$

Outdoor

9 (69.2) 


\section{DISCUSSION}

This is the first study that evaluates the compliance on smoke free legislation in the gazetted area under TBAR initiative that has taken place over the past two years. Within that period, numerous efforts have been made by various parties to provide public awareness and compliance with TBAR and smoke-free regulation in this area. The aim of the initiative is to achieve $100 \%$ smoke free environment in order to effectively protect people from exposure to tobacco smoke, as required by Article 8 FCTC $^{8}$. Unfortunately, this study demonstrates an average overall compliance of only $66.2 \%$, which is still far from the target. As a matter of fact, this level of compliance is much lower compared to the level of compliances in other smoke free areas in countries such as India, Guatemala, United States, Ireland and France where compliances were reported as more than $70 \%^{9-13}$.

The current study also demonstrates that average compliance on smoke free legislation was better indoor $(67.4 \%)$ as compared to outdoor (58.9\%). Thirteen smokers were found actively smoking during the 30 minutes observation and more than half of them were smoking outdoors. This could be due to lack and poor visibility of signage where more than half of the observed outdoor areas did not have any signage. The situation was similar with the study done in Catalan Hospitals ${ }^{14}$ and public buildings in Turkey ${ }^{15}$ where the public compliance on smoke free legislation were much better indoor compared to outdoor. Only $57.6 \%$ of the participants in Catalan study had seen information banners on smoke free legislation ${ }^{14}$.

Moreover, compliance regarding the provision of outdoor signage was the worst compliance observed in this study. Most places observed here showed no informative signage on smokefree policy, either indoor $(54.5 \%)$ or outdoor (71.4\%). Worse still some of these signages were not in proper size and lack of appropriate standard information content as required by law. This is a serious issue as proper informative signage plays a very important role in ensuring compliance with smoke-free regulations. Foreign tourists who visit this area may not be aware of the smoke-free regulations without a visible, clear, and appropriate informative signage. In addition, previous studies showed that signage is one of the important components in enforcement package that was successfully increased smoker's compliance in outdoor smoke free $\operatorname{area}^{16}$. The presence of smoke free signages would decrease smoking activities ${ }^{17}$ and was significantly associated with lower levels of third hand tobacco smoke pollutants ${ }^{18}$. Furthermore, signage also plays a vital supportive role as a guide to empower non-smokers to speak up and request smokers to stop smoking ${ }^{19}$.
As a popular recreation area, public parks and beaches, Batu Buruk has become one of the state icons and main tourist attraction in Terengganu. Therefore, it is imperative to ensure compliance with outdoor smoke-free regulations not only to limit public exposure to second-hand smoke in outdoor settings, but also to prevent pollution from cigarette-related littering. As a matter of fact, there was a report showing volunteers collected over 5,000 cigarette butts in Batu Buruk Beach within just two hours ${ }^{20}$. It is already known that cigarette butts, when accumulated on beaches either from direct littering or transported from other areas, can cause environmental and visual pollution, damage to biota, and socio-economic impacts ${ }^{21}$. Therefore, if there is no effective control of the situation, it will soon affect the state's image, economy, and the tourism industry.

Finally, there is one positive finding during this observation whereby not a single smoking aid or receptacles such as lighter, ashtray, or ashbin was found either indoor or outdoor spaces in this area. The possibility that premises owners hide smoking related items at their premises during data collection was less likely because they were not informed about the observation prior to the research visit. This is considerably a good sign that shows good responsibility and support from the premises owners towards smoke free initiative. It is an essential element in supporting the success of TBAR initiative as evidenced in previous studies where the presence of smoking receptacles was an important determinant of a smoke-free legislation's success ${ }^{22}$.

Although this study provides important findings, it has some limitations related to its crosssectional design and data collection approach. Results may be bias since data collectors only visit and observed the areas for a limited period of times (30 minutes for each premise). Furthermore, due to the limited study period, the observation was done only on week day which may overstate compliance as compared to observation done during peak day on weekends or public holidays. An observational indicator such as detecting the smell of tobacco smoke can also be questionable since it is subjective and may vary greatly between data collectors ${ }^{7}$. Thus, future study could use particle measurement tool as a better objective measurement to detect the presence of tobacco smoke. In addition, a future qualitative in-depth interview with local residents and policy maker will also complement our findings.

\section{CONCLUSION}

The current study showed that overall compliance was unsatisfactory. Smoking 
activities were still happening in this area despite of educational, promotional and enforcement efforts undertaken by various parties. Therefore, enforcement activities must be increased and strengthened. Health education and promotion also plays an important role and should focus on empowering the community to reprimand smokers for smoking in public area.

The worst finding was lack of visible and proper signage as required by the law. Therefore, the authorities should place more signage especially in outdoor public spaces where smoking violations occurred more often. Signage placement is also critical to ensure that it is noticeable and clearly visible by the public. Monitoring and evaluation also need to be conducted periodically to identify weaknesses and to find room for compliance improvement. Establishing near $100 \%$ compliance is very important as it is the only effective way to ensure the non-smokers are fully protected from second-hand smoke. Hence, all local stakeholders need to work together to support this initiative. The future success of this TBAR initiative will serve as an example and benchmark for similar initiatives elsewhere.

\section{Conflict of interest}

The authors declare no potential conflict of interest.

\section{Acknowledgements}

The authors would like to thank all year 3 group 1 medical students from Sultan Zainal Abidin University (UniSZA) session 2018/2019 for conducting this study. We would also like to take this opportunity to express our sincere gratitude and appreciation to the premise owners and workers in Terengganu Bebas Asap Rokok (TBAR) area who have given their heartwarming welcome and co-operation in allowing us to conduct the survey and research smoothly. This research would not be a success without the help of $\mathrm{Hj}$. Mohd bin Ismail, the President of the Village Community Management Council (MPKK) in Kampung Batu Buruk who assisted us throughout the survey by providing support and welcoming us into the village with open arms.

\section{REFERENCES}

1. World Health Organization. WHO Report on The Global Tobacco Epidemic. MPOWER Packag. 2008;

2. Rashid A, Manan AA, Yahya N, Ibrahim L. The support for smoke free policy and how it is influenced by tolerance to smoking - Experience of a developing country. Vol. 9, PLoS ONE. 2014.

3. Hyland A, Barnoya J, Corral JE. Smoke-free air policies: Past, present and future. Tob Control. 2012;21(2).

4. ABDULLAH NH. Kenyataan Akhbar KPK 13 Mei 2018 - Sempena Southeast Asia Conference On Tobacco Control 2018 [Internet]. From the Desk of the DirectorGeneral of Health Malaysia. 2018 [cited 2019 Jun 20]. Available from: https: / / kpkesihatan.com/2018/05/1 3/kenyataan-akhbar-kpk-13-mei2018-sempena-southeast-asiaconference-on-tobacco-control2018/

5. Mohamed AA. Terengganu Bebas Asap Rokok Dan Bersih [Internet]. Buletin Online. 2019 [cited 2019 Jun 20]. Available from: https://buletinonline.net/v7/index. php/terengganu-bebas-asap-rokokdan-bersih/

6. Bernama. Op Larangan Merokok: 172 Notis Dikeluarkan di Pantai Batu Buruk [Internet]. Mynewshub. 2018 [cited 2019 Jun 20]. Available from: https: / / www. mynewshub.tv/terkini / op-larangan-merokok-172-notisdikeluarkan-di-pantai-batu-buruk/

7. Johanna Birckmayer, Ellen Feighery, Maria Carmona, Karen Friend, Benjamin Apelberg, Lisa Hepp and Erika Avila-Tang and HS. Assessing Compliance with Smoke-Free Laws [Internet]. International Union Against Tuberculosis and Lung Disease; 2014. Available from: https: / / theunion.org/sites/default/f iles/2020-08/complianceguide_v4smallerfile.pdf

8. World Health Organization (WHO). WHO Report on The Global Tobacco Epidemic, 2009. Implementing smoke-free environments [Internet]. 2009. Available from: https: / /www.who.int/tobacco/mpo wer/2009/gtcr_download/en/

9. Mark Engelen, Farrelly M, Hyland A. The Health and Economic Impact of New York's Clean Indoor Air Act. [Internet]. New York State Department of Health; 2006. Available from: https://www.health.ny.gov/preventi on/tobacco_control/docs/ciaa_impa ct_report.pdf

10. Fong GT, Hyland A, Borland R, Hammond D, Hastings G, McNeill A, et al. Reductions in tobacco smoke 
pollution and increases in support for smoke-free public places following the implementation of comprehensive smoke-free workplace legislation in the Republic of Ireland: Findings from the ITC Ireland/UK Survey. Tob Control. 2006;15(SUPPL. 3).

11. Nagelhout GE, Mons U, Allwright S, Guignard R, Beck F, Fong GT, et al. Prevalence and predictors of smoking in "smoke-free" bars. Findings from the International Tobacco Control (ITC) Europe Surveys. Soc Sci Med. $2011 ; 72(10)$.

12. Barnoya J, Monzon JC, Briz P, NavasAcien A. Compliance to the smokefree law in Guatemala 5-years after implementation. BMC Public Health. 2016;16(1).

13. Goel S, Sharma D, Gupta R, Mahajan V. Compliance with smoke-free legislation and smoking behaviour: Observational field study from Punjab, India. Tob Control. 2018;27(4).

14. Antón $\mathrm{L}$, Fu M, Castellano $\mathrm{Y}$, Riccobene A, Fernández $\mathrm{E}$, Martínez C. Compliance with indoor and outdoor smoke-free ban in Catalan hospitals: what do patients think? Tob Induc Dis. 2018;16(1).

15. Navas-Acien A, Çarkoğlu A, Ergör G, Hayran M, Ergüder T, Kaplan B, et al. Compliance with smoke-free legislation within public buildings: a cross-sectional study in Turkey. Bull World Health Organ. 2016;94(2).

16. Harris KJ, Stearns JN, Kovach RG, Harrar SW. Enforcing an outdoor smoking ban on a college campus:
Effects of a multicomponent approach. J Am Coll Heal. 2009;58(2).

17. Platter HN, Pokorny SB. Smoke-free signage in public parks: Impacts on smoking behaviour. Tob Control. 2018;27(4).

18. Matt GE, Fortmann AL, Quintana PJE, Zakarian JM, Romero RA, Chatfield DA, et al. Towards smoke-free rental cars: An evaluation of voluntary smoking restrictions in California. Tob Control. 2013;22(3).

19. Poland BD, Stockton L, Ashley MJ, Pederson L, Cohen J, Ferrence R, et al. Interactions between smokers and non-smokers in public places: A qualitative study. Can J Public Heal. 1999;90(5).

20. Abu Bakar A. Puntung rokok cemari Pantai Batu Buruk [Internet]. BH Online. 2018 [cited 2019 Jun 20]. Available from: https: //www.bharian.com.my/berita /wilayah/2018/04/407660/puntungrokok-cemari-pantai-batu-buruk

21. Araújo MCB, Costa MF. A critical review of the issue of cigarette butt pollution in coastal environments. Vol. 172, Environmental Research. 2019.

22. Vardavas $\mathrm{Cl}$, Agaku I, Patelarou E, Anagnostopoulos N, Nakou C, Dramba $\mathrm{V}$, et al. Ashtrays and Signage as Determinants of a Smoke-Free Legislation's Success. PLoS One. 2013;8(9). 